\title{
PEMBINAAN PENGELOLAAN KEUANGAN DAN TEKNOLOGI INFORMASI PADA INDUSTRI SNACK DAN COOKIES BATAM
}

\author{
Dian Efriyenti*1, Nita $^{2}$, Budi Widiantoro ${ }^{3}$ \\ ${ }^{3,4}$ Program Studi Akuntansi, Fakultas Ilmu Sosial dan Humaniora, Universitas Putera Batam \\ e-mail: ${ }^{* 1}$ dianefriyenty@gmail.com, ${ }^{2}$ nita.zeng.nz@gmail.com, ${ }^{3}$ Bwidiyant@gmail.com
}

\begin{tabular}{|c|c|}
\hline Informasi Artikel & Abstract \\
\hline $\begin{array}{l}\text { Diterima Redaksi: } 08 \text { August } 2019 \\
\text { Revisi Akhir: } 16 \text { Sept } 2019 \\
\text { Diterbitkan Online: } 27 \text { Sept } 2019 \\
\text { Kata Kunci } \\
\text { Pembinaan Pengelolaan Keuangan, } \\
\text { Teknologi Informasi } \\
\text { Korespondensi } \\
\text { No. HP: } 081275959077\end{array}$ & $\begin{array}{l}\text { The problems currently faced are financial reports compiled in each } \\
\text { period not yet accounting standard, lack of knowledge and } \\
\text { understanding of Micro, Small and Medium Enterprises in the } \\
\text { preparation of financial reports to produce financial and information } \\
\text { technology information, increased production produced by MSMEs } \\
\text { and often neglect not recording financial problems related to material } \\
\text { expenditure, production process to marketing, so that prices are } \\
\text { formed based on estimates only. In fact, most of the chips and } \\
\text { processed cake pasters still don't hold financial records properly. The } \\
\text { method used in fostering the Snack And Cookies Industry in Batam } \\
\text { City will be given, namely the survey method, lecture method, } \\
\text { discussion method and training method. The results of the UKM } \\
\text { service felt that there was still a need to adjust to the preparation of } \\
\text { financial statements with the financial accounting standards of } \\
\text { entities without public accountability, to practice daily input of } \\
\text { financial data with Ms. Excel in improving the financial performance } \\
\text { of SMEs running smoothly. }\end{array}$ \\
\hline
\end{tabular}

\section{PENDAHULUAN}

Analisis Situasi

Usaha mikro kecil dan menengah atau UMKM diatur berdasarkan (Republik Indonesia, 2008) tentang usaha mikro kecil dan menengah terkait usaha produktif milik orang perseorangan atau badan usaha yang memenuhi kriteria dalam Undang-Undang ini.

Berdasarkan hasil penelitian (Maseko, 2011) yang berjudul "Accounting Practises of SMES in Zimbabwe : An Investigative Study of Record Keeping for Performance Measurement" bahwa 50\% UMKM tidak menyimpan lengkap catatan akuntansi karena kurangnya pengetahuan akuntansi dan penggunaan informasi akuntansi sehingga tidak dapat dilakukan pengukuran kinerja keuangan usaha. Sama halnya dengan hasil penelitian (Kwabena,
2013) yang berjudul "Accounting Practices of SMES: A Case Study of Kumasi Metropolis in Ghana" bahwa 60\% UMKM mengalami kesulitan untuk akses keuangan dari lembaga keuangan karena UMKM tersebut tidak memiliki catatan keuangan yang tepat. Oleh karena itu disarankan pada UMKM untuk membuat dan menyimpan catatan akuntansi yang rinci. Sehingga menghasilkan laporan keuangan yang tepat dan dapat meningkatkan aksessibilitas UMKM terhadap lembaga keuangan mikro.

Sejalan dengan pendapat (Maseko, 2011) bahwa UMKM sebaiknya harus menyajikan informasi keuangan untuk mempermudah mendapatkan pinjaman dari bank dan lembaga keuangan mikro lainnya serta asuransi yang diperoleh dari pihak bank dapat meminimalkan risiko kredit dan kegagalan bisnis. Hal ini juga 
sejalan dengan hasil penelitian (Salmiah, 2015) bahwa 83\% UMKM di kota Pekanbaru tidak memahami isi SAK ETAP dan tidak menyajikan laporan keuangan. Hal ini karena minimnya pengetahuan dan pemahaman UMKM dalam penyusunan laporan keuangan untuk menghasilkan informasi keuangan dengan teknologi yang ada. Untuk mengatasi masalah pelaporan keuangan UMKM adalah melalui sosialisasi tentang pengelolaan catatan keuangan. Serta teknologi informasi yang digunakan UKM Snack dan Cookies masih berdasarkan catatan buku besar dengan menggunakan manual, walaupun perkembangan teknologi informasi sudah maju namun belum digunakan oleh UKM Snack dan Cookies dengan permasalahan kurangnya pengetahuan dibidang komputer dan memakan waktu dan biaya pembelian peralatan.

Berdasarkan observasi yang dilakukan pada pelaku usaha mikro di kota Batam, kendala yang dihadapi pelaku usaha mikro untuk mengembangkan bisnis adalah permodalan, pengelolaan keuangan, administrasi izin usaha, proses dan pengemasan produksi serta teknologi informasi. Untuk itu perlunya menumbuhkan kemampuan dalam bentuk pengelolaan dan penyusunan laporan keuangan sehingga diperoleh informasi akuntansi yang dijadikan sebagai sumber informasi keuangan bagi stakeholder untuk mewujudkan kemitraan antara UMKM dengan pelaku usaha besar dan entitas bisnis yang lebih luas. Informasi akuntansi berperan dalam keberhasilan pengelolaan usaha karena informasi yang dihasilkan dapat mengungkapkan kinerja keuangan suatu usaha.

Salah satu jenis UMKM yang banyak digeluti oleh masyarakat di wilayah Batam khususnya pada daerah Kecamatan Sagulung adalah usaha industri makanan

Dian Efriyenti ringan keripik dan kue basah. Biasanya makanan ini sebagai teman pada saat minum teh atau sebagai pengganti kerupuk ketika makan nasi. Di kota Batam khususnya pada Kecamatam Sagulung cukup banyak masyarakat yang menggeluti usaha pembuatan keripik dan kue-kue basah ini. Permasalahan yang sering dihadapi usaha ini yaitu UMKM belum memiliki pengetahuan dalam pengelolaan keuangan usaha. Untuk itu pelaku usaha Snack dan Cookies ini membutuhkan pelatihan dan pendampingan dalam penyusunan laporan keuangan yang intens dan penting kiranya pelaku usaha mitra ini mengetahui dan memahami manajemen pengelolaan keuangan usaha serta teknologi informasi.

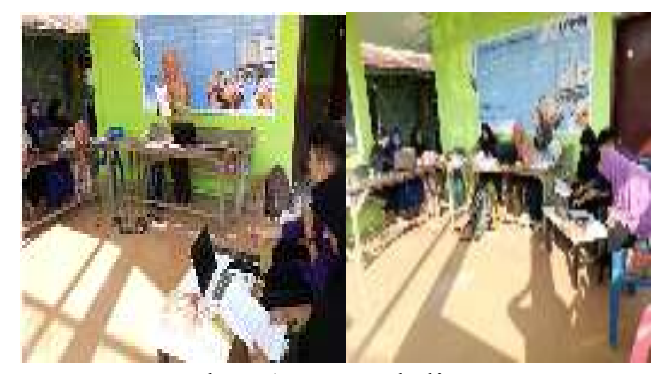

Gambar 1 Pengabdian

Dalam program ini UMKM Snack dan Cookies yaitu Usaha keripik dan kue-kue basah dengan pemilik usaha yaitu Ibu Elis Sriyani Nurdianti. Usaha Snack dan Cookies ini telah berdiri 3 tahun yang berlokasi di Sagulung Bersatu RT.02 RW.09 Kelurahan Sei Lekop Kecamatan Sagulung Kota Batam.

Industri olahan aneka keripik dan aneka kue-kue basah ini merupakan bagian dari industri kecil rumahan (home industry) khas yang ada di daerah Sagulung dan terbukti mampu bertahan serta berkembang cukup baik hingga saat ini. Hal ini terlihat dengan bertambahnya jumlah pengrajin keripik olahan dan kuekue basah di daerah tersebut. Kondisi sekarang ini, industri kecil didaerah tersebut memiliki potensi untuk berkembang menjadi lebih baik dan lebih 
besar karena semakin dikenal tidak hanya di wilayah Batam namun juga sudah dikenal di luar kota Batam.

Berkembangnya beberapa pengrajin industri kecil keripik olahan di daerah Sagulung Kota Batam dalam beberapa pengrajin melakukan diversivikasi hasil olahan dengan berbagai ukuran, bentuk, dan jenis. Bertambahnya jumlah produksi yang dihasilkan pengrajin sering mengabaikan tidak melakukan pencatatan masalah keuangan terkait dengan belanja bahan, proses produksi sampai ke pemasaran dan teknologi informasi, sehingga harga terbentuk hanya berdasarkan perkiraan.

Masalah pencatatan dan pelaporan keuangan merupakan hal yang sangat penting bagi kegiatan usaha produksi maupun perdagangan. Pencatatan keuangan pada dasarnya merupakan kegiatan akuntansi untuk memberikan pertanggungajawaban atas kegiatan dagang yang dilakukan. Pertanggungjawaban ini sangat penting dalam rangka upaya mengembangkan usaha yang telah dan akan dilakukan serta untuk mengetahui omset yang diperoleh. Pada kenyataannya sebagian besar pengrajin keripik olahan masih belum menyelenggarakan pencatatan keuangan dengan baik.

Melihat manfaat yang dihasilkan akuntansi, pelaku UMKM seharusnya sadar bahwa akuntansi penting bagi usahanya. Penggunaan akuntansi dan teknologi informasi dapat mendukung kemajuan UMKM khususnya dalam hal keuangan serta teknologi informasi. Peningkatan laba juga dapat direncanakan dengan menggunakan akuntansi. Dengan tingkat laba yang semakin meningkat, perkembangan UMKM akan menjadi lebih baik. Sehingga UMKM akan benar-benar menjadi salah satu solusi bagi masalah perekonomian di Indonesia. Namun, masih banyak UMKM yang belum menggunakan akuntansi dalam menunjang kegiatan bisnisnya. Alasan pelaku UMKM tidak menggunakan akuntansi antara lain adalah akuntansi dianggap sesuatu yang sulit dan tidak penting.

Berdasarkan permasalahan tersebut, perlu diadakan kegiatan bagi pelaku UMKM dalam hal mengelola keuangan dengan menggunakan akuntansi. Berdasarkan penjelasan diatas, maka pembinaan yang dilakukan adalah tentang Pembinaan Pengelolaan Keuangan Dan Teknologi Informasi Pada Industri Makanan Ringan Snack Dan Cookies Kota Batam.

\section{Permasalahan}

Permasalahan yang sedang dihadapi Industri makanan ringan snack dan cookies, berdasarkan survey yang dilaksanakan adalah:

1. Laporan keuangan belum sesuai dengan standar akuntansi keuangan.

2. Minimnya pengetahuan dan pemahaman UMKM dalam penyusunan laporan keuangan untuk menghasilkan informasi keuangan.

3. Minimnya pengetahuan dan pemahaman UMKM dalam teknologi informasi.

4. Bertambahnya jumlah produksi yang dihasilkan pengrajin sering mengabaikan tidak melakukan pencatatan masalah keuangan terkait dengan belanja bahan, proses produksi sampai ke pemasaran, sehingga harga terbentuk hanya berdasarkan perkiraan.

5. Pada kenyataannya sebagian besar pengrajin keripik dan kue-kue basah olahan masih belum menyelenggarakan pencatatan keuangan dengan baik. 


\section{METODE}

Pelaksanaan kegiatan Pengabdian Pada Masyarakat ini dilakukan dengan menggunakan metode ceramah, tutorial, dan diskusi seta lathan. Adapun sistematika pelaksanaan kegiatan pengabdian ini adalah sebagai berikut:

\section{a. Langkah 1 (Metode Ceramah):}

Peserta diberikan motivasi agar memiliki kemauan untuk menggunakan akuntansi dalam kegiatan bisnisnya. Selain itu, peserta diberikan materi gambaran umum tentang akuntansi UMKM dan peran penting akuntansi bagi UMKM. Langkah pertama diselenggarakan selama $1 \mathrm{jam}$.

b. Langkah ke-2 (Metode Tutorial):

Peserta pelatihan diberikan materi akuntansi mulai dari pencatatan sampai dengan menyusun laporan keuangan dengan bantuan program excel. Langkah kedua diselenggarakan selama 2 jam.

c. Langkah ke-3 (Metode Diskusi):

Peserta pelatihan diberikan kesemp atan untuk mendiskusikan permasalahan yang berkaitan dengan keuangan dan teknologi informasi UMKM yang selama ini dihadapi. Langkah ketiga diselenggarakan selama 1 jam.

\section{d. Langkah ke-4 (Metode Latihan)}

Kegiatan pembinaan ini dilakukan untuk membina serta melatih para pelaku UKM dalam menganalisa transaksi-transaksi secara nyata hingga proses penyusunan laporan keuangan. Tujuan laporan keuangan ini disajikan bukan hanya pihak internal saja tetapi juga pihak eksternal terutama jika usaha kecil menengah ingin memperluas usahanya untuk menambah modal dengan melakukan pinjaman kepada pihak debitur serta pengembangan usahanya.

\section{HASIL DAN PEMBAHASAN}

Hasil Pengabdian

Pengabdian masyarakat yang berupa pembinaan telah direalisasikan sebanyak 2 kali pertemuan yang dilaksanakan setiap pukul 14.00 sampai dengan 17.00 WIB. Pembinaan dilakukan oleh 6 (enam) orang dari ibu-ibu kelompok UKM Snack Dan Cookies. Teknis pelaksanaan pembinaan dilakukan dengan metode ceramah, diskusi dan latihan penyusunan laporan Keuangan. Berdasarkan metode tersebut maka Tim pengabdi secara langsung memandu dan membina UMKM dalam penyusunan laporan keuangan sesuai dengan SAKETAP yang benar. Adapun penjelasan pada setiap pertemuan sebagai berikut:

\section{Pertemuan Pertama}

Pelaksanaan pengabdian masyarakat pertemuan pertama dilaksanakan pada Selasa, 7 Agustus 2018, dimana kegiatan pertemuan saat itu diawali dengan pembukaan oleh Ketua, dilanjutkan penyampaian materi topik materi Pengantar Akuntansi UMKM. Materi ini membahas pentingnya akuntansi UMKM disertai membahas soal terkait transaksi UMKM serta membahas soal dan jawaban jurnal umum. Kegiatan ini disampaikan oleh Ketua.

Materi kedua ini juga disampaikan oleh Anggota 2 dengan topik transaksi-transaksi, buku besar, neraca akuntansi UMKM dan pelaporan akuntansi UMKM dengan bantuan menggunakan bantuan computer dalam program Ms. Excel untuk mempermudah penginputan data keuangan dalam mempraktekannya. Sedangkan materi ketiga yang disampaikan oleh Anggota 1 terkait jurnal penyesuaian, neraca saldo setelah penyesuaian.

2. Pertemuan Kedua 
Pelaksanaan pengabdian masyarakat pertemuan kedua dilaksanakan pada Selasa, 14 Agustus 2018. Kegiatan pertemuan ini berupa penjelasan topik praktik akuntansi UMKM yang disampaikan oleh Ketua pada pukul 14.00 serta dilanjutkan oleh Ketua terkait penjelasan materi laporan keuangan yang sesuai dengan standar akuntansi keuangan entitas tanpa akuntabilitas publik (SAK-ETAP) yang terdiri dari laporan laba rugi, laporan posisi keuangan, laporan perubahan ekuitas, dan laporan arus kas. Pada materi laporan laba rugi dan laporan posisi keuangan dibahas jawabannya serta paparannya oleh Ketua. Kemudian setelah itu selesai pada pukul 15.00 sampai dengan 16.00 WIB dilanjutkan pembahasan materi dan contoh soal terkait laporan perubahan ekuitas yang disampaikan oleh Anggota 1, serta materi dan contoh kasus laporan arus kas dibahas oleh Anggota 2. Tepat pada jam 16.00 Tim pengabdi memberikan sesi latihan terkait transaksi bisnis UMKM secara mandiri yang didampingi oleh Anggota 1 dan Anggota 2. Tujuannya agar mendapatkan feedback dari yang sudah disampaikan.

Selanjutnya sisa pembinaan peserta diberikan kesempatan untuk mendiskusikan permasalahan yang berkaitan dengan usaha yang sudah mereka jalani yang didampingi oleh Ketua, Anggota 1 dan Anggota 2.

\section{Pembahasan}

Kegiatan yang sudah dilaksanakan sebanyak 2 kali pertemuan dapat dijelaskan bahwa kegiatan dapat dijalankan sesuai dengan rencana. Dosen dan dua orang mahasiswanya yang memberikan bantuan kepada UKM dalam penyusunan laporan keuangan yang berstandar ETAP. Materi pertama yang diberikan adalah pengenalan atau pendahuluan mengenai akuntansi. Pemateri memberikan penjelasan pentingnya akuntansi bagi UMKM serta membahas materi dan soal-soal dari jurnal umum sampai dengan laporan keuangan. Sebagian besar audiens belum mengerti fungsi akuntansi, bahkan sebagian besar peserta pembinaan menganggap bahwa akuntansi adalah bidang yang rumit, susah, merepotkan, menghabiskan waktu.

Materi pertama diisi dengan penguatan pentingnya akuntansi bagi usaha kecil (UMKM) dan data-data transaksi yang harus dimasukan didalam jurnal umum. Pada sesi ini terjadi diskusi yang menarik antara audience dengan pemateri mengenai konsep dasar usaha terkait usaha yang UKM tekuni. Dilanjutkan materi kedua mengenai transaksi-transaksi akuntansi UMKM. Pada sesi ini, masing-masing audience diminta menjelaskan aktivitas operasi masing-masing usaha mereka. Selanjutnya diidentifikasi aktivitasaktivitas ekonomi terkait pencatatan akuntansi. Aktivitas yang diidentifikasi tersebut diawali dari aktivitas memulai usaha (investasi awal), transaksi pembelian bahan baku, pembelanjaan atau pengeluaran, pemasukan atau penerimaan. Setelah mencatat transaksi akuntansi, materi berikutnya menyusun laporan keuangan. Sebagai latihan, peserta pembinaan diminta untuk menjawab soal latihan yang telah disediakan oleh Tim Pengabdi dengan menjawabnya menggunakan bantuan computer dalam program Ms. Excel. Sesi terakhir peserta diberikan diskusi terkait pencatatan keuangan di usaha UKM.

Pembinaan hari kedua dilaksanakan hari Selasa, 14 Agustus 2018, peserta diberikan gambaran tentang materi dan praktik laporan keuangan yang terdiri dari laporan laba rugi, laporan perubahan ekuitas, laporan neraca serta laporan arus kas. Pada sesi awal peserta bertanya dan berdiskusi tentang transaksi dan pencatatan yang telah mereka buat. Beberapa dari peserta masih kebingungan mencatat transaksi akuntansi. Sambil beristirahat dan menyantapi snack yang ada, diskusi dilanjutkan membahas 
penyusunan laporan keuangan dalam prakteknya. Serta sisa jam16.00 WIB pembinaan digunakan untuk pendampingan kepada peserta pembinaan akuntansi UMKM secara mandiri dimasing-masing tempat untuk menjawab latihan yang telah disediakan Tim Pengabdi.

Pelaksanaan pengabdian yang dilaksanakan ditemukan kendala yang signifikan, namun dapat diatasi setelah kegiatan dilaksanakan sampai selesai, kendala yang terjadi adalah:

1. Sebagian besar peserta menyusun laporan keuangan belum sesuai standar akuntansi keuangan entitas tanpa akuntabilitas publik.

2. Kesulitan mencocokan waktu Tim Pengabdi dengan peserta pengabdian.

3. Laporan keuangan yang telah biasa disusun oleh UKM tidak bisa diganti secara langsung.

4. Penginputan data keuangan dengan menggunakan computer di Ms. Excel tidak bisa diganti secara langsung.

5. Keikutsertaan atau kehadiran peserta yang relative rendah hanya 6 orang dari 10 orang undangan yang telah dikoordinir oleh Ketua UKM Snack Dan Cookies.

\section{KESIMPULAN}

Berdasarkan penjelasan hasil dan pembahasan, maka didapatkan simpulan sebagai berikut:

1. Pelaksanaan pengabdian masyarakat yang dilakukan dapat dilaksanakan sesuai dengan jadwal yang direncanakan

2. Kegiatan dilaksanakan 2 kali pertemuan, dimana setiap pertemuan membahas materi yang tidak bisa diacak dalam pelaksnaannya. Hal ini disebabkan karena penyusunan laporan keuangan memiliki siklus akuntansi, sehingga pelaksanaanya harus berurutan.

3. Usaha Kecil Menengah (UKM) yang sudah dibina dapat melakukan penyusunan laporan keuangan secara mandiri, sehingga UKM Snack dan Cookies mampu menyusun laporan keuangan berstandar SAK-ETAP.

4. Pelaku Usaha Kecil Menengah (UKM) Snack dan Cookies yang telah dibina dalam penyusunan laporan keuangan dengan bantuan Ms Excel, perlu adanya latihan-latihan secara mandiri dalam prakteknya sehari-hari yang dilakukan ibu-ibu UKM dalam hal penginputan data keuangan. Agar dapat membiasakan dalam kebutuhan usahanya sehari-hari.

5. Kegiatan pembinaan akuntansi UMKM bagi usaha mikro, kecil, menengah (UMKM) untuk meningkatkan kinerja keuangan UMKM berjalan dengan lancar. Semua peserta antusias mengikuti acara hingga selesai dan merasakan manfaat pembinaan bagi kemajuan usaha mereka.

\section{SARAN}

Berdasarkan kesimpulan kegiatan di atas, maka disarankan kepada semua pihak agar terutama bagi:

1. Bagi Pelaku Usaha Kecil Menengah diharapkan dapat menerapkan penyusunan laporan keuangan sesuai dengan standar akuntansi yang diterapkan saat ini serta dapat menginputnya langsung ke dalam $M s$. Excel yang memiliki fungsi dan manfaat buat internal dan eksternal atau semua pihak-pihak yang berkepentingan.

2. Tim Pengabdi yang akan melaksanakan pengabdian berikutnya, maka disarankan dapat dilaksanakan kembali dengan peserta (audience) yang lebih banyak atau luas, dengan topik pajak penghasilan yang harus dibayarkan, mengingat UMKM akan dikenai pajak sebesar $0,5-2 \%$ dari total omsetnya dan penginputan data keuangan dengan bantuan software akuntansi.

Pembinaan Pengelolaan Keuangan 


\section{UCAPAN TERIMA KASIH}

Penulis mengucapkan terima kasih kepada Universitas Putera Batam yang telah memberi dukungan financial terhadap pengabdian ini. Serta kepada lembaga penelitian dan pengabdian kepada masyarakat Universitas Putera Batam yang telah mereview proposal hingga laporan pengabdian ini.

\section{DAFTAR PUSTAKA}

[1] Kwabena, 2013, Accounting Practices of SMES: A Case Study of Kumasi Metropolis in Ghana. International Journal of Business and Management, 8(24), 2129. https://doi.org/10.5539

[2] Maseko, M, 2011, Accounting Practices of SMES in Zimbabwe: An Investigative Study of Record Keeping for Performance Measurement. Journal of Accounting and TaxationNo Title. Journal of Accounting and Taxation, 3(8), 171-181, https://doi.org/10.5897/JAT.11031

[3] Republik Indonesia, Peraturan. Undang-Undang Nomor 20 Tahun 2008 tentang usaha mikro kecil dan menengah, Pub. L. No. Undang-Undang Nomor 20 Tahun 2008 (2008).

[4] Salmiah, I, (2015), Analisis Penerapan Akuntansi dan Kesesuaiannya dengan Standar Akuntansi Keuangan Entitas Tanpa Akuntabilitas Publik Pada UMKM Kota Pekanbaru. Jurnal Akuntansi, 3(2), 11-19. 